\title{
Decolonising youth ministry models? Challenges and opportunities in Africa
}

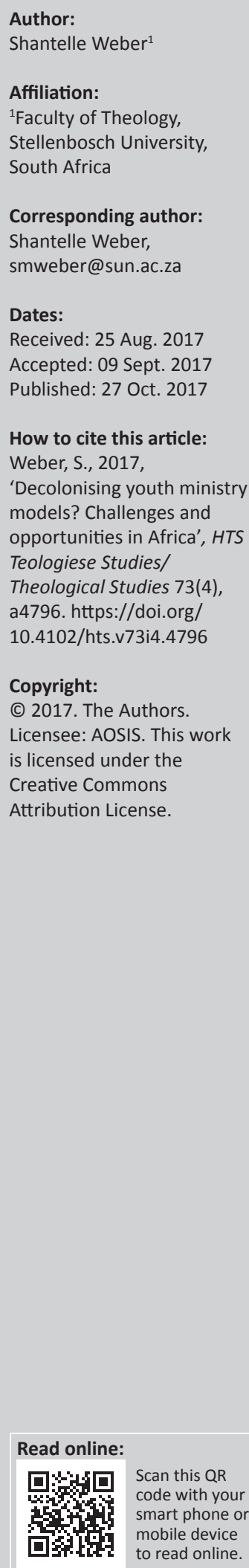

\begin{abstract}
Anyone involved in youth ministry will be able to testify to the fact that no perfect youth ministry model exists. Youth ministry models employed should consider the vision, mission and needs of the contexts in which they are to be used. Although not new, the term 'decolonise' has become a prominent part of African discourses after the 2015 and 2016 student protests at various university campuses in South Africa. A strong call to decolonise theology and how we do church has been included in these calls. Students have argued against a theology and ecclesiology that is exclusively based on European and other international foundations. My challenge with all these discussions has been discerning the difference between decolonisation and contextualisation within theology. I have often wondered whether those calling for a decolonised theology are actually referring to problems connected to a theology that is not correctly contextualised. When I ask whether youth ministry models in Africa should be decolonised, I do so in the awareness that these models have brought with them both challenges and opportunities for ministry on this continent. Youth ministry models employed in Africa need to stem from the contextual situations and readings of the biblical text in which they find themselves. This article is aimed at exploring the work of Scripture Union as a mission-based youth ministry model in Africa in view of the present call to decolonise theology.
\end{abstract}

\section{Introduction}

We need to employ all of our resources to start an effective nucleus of SU work in the Black community and give all the help there is in the world for that nucleus to expand, so that the young people of South Africa, Black and White, will know the Lord Jesus Christ and honour Him in their lives. (Philip Nkabinde in Prest 1988:210)

In a chapter entitled 'The Perfect youth ministry model', Mark DeVries (in Dean et al. 2001:109-120) argues that no perfect youth ministry model exists. Rather that youth ministry models employed should consider the vision, mission and needs of the contexts in which they are to be used. Hendriks (2004) also argues that one should take the context, identity and processes followed within specific congregations seriously before making recommendations on how congregations in Africa should be functioning. In a recent article entitled 'A (South) African voice on youth ministry research: Powerful or powerless?', I (Weber 2015:1) argue that youth ministry practice in Africa has relied heavily on research composed by American and English or German scholars and practitioners. This has also been evident in how international mission-focused youth ministry organisations, such as Youth for Christ, Scripture Union (hereafter SU), Youth with a Mission and others have taken root and have been flourishing in Africa for decades. The main aim of this article was to argue that international research on youth ministry is valuable in an African context, but this research needs to be culturally contextualised (ibid).

Although not new, the term 'decolonise' has become a prominent part of African discourses after the 2015 and 2016 student protests at various university campuses in South Africa. Students in South Africa took to the streets to protest against language, curriculum and university structures (including fees) which they deemed unjust and based on colonised systems. Some (Al-Zubaidi \& Luckscheiter 2013) have even commented that this has not been unique to the present South African context but has correlation with both the Soweto uprisings of 1976 and also other political protests on our continent. The decolonisation discussion has impacted varying academic disciplines, including theology. A strong call to decolonise theology and how we do church has been included in these calls. Students have argued against a theology and ecclesiology that is exclusively based on European and other international foundations. My challenge with all these discussions has been discerning the difference between decolonisation and contextualisation within theology. I have often wondered whether those calling for a decolonised theology are actually referring to problems connected to a theology that is not correctly contextualised. 
Youth ministry and how it is taught and practiced in Africa is not exempt from this tension. It is this tension that has led to my use of a question mark within my title for this article. As mentioned in a previous paper (Weber 2015), many youth ministry models have been used in Africa either through the resources sourced internationally or through mission organisations settling in Africa. My exploration in this article is based on my curiosity about these youth ministry models. I have noted several in my earlier argument but will restrict this article to the ministry of SU (of which I too have been a part). How has it been possible that a European founded mission organisation like SU has flourished for many decades within Africa? How has church planting through the foundation of schools (which seems to be a common earlyday mission strategy) benefitted from the ministry of SU? Has anyone ever challenged this European way of doing youth ministry from an African perspective? When I ask whether youth ministry models in Africa should be decolonised, I do so in the awareness that these models have brought with them both challenges and opportunities for ministry on this continent. I have heard many stories and met many people who have become Christians and later even leaders through the ministry of SU. I still continue to hear how active this organisation is in many schools in Africa. Yet, I am also curious about why the work of SU (like many mission organisations in Africa) has and still is accompanied by an international person leading or administrating it. I am curious as to why it took so long to entrust this work to local leaders. I am also curious about why Africans still source international funding for this work today and what the detail of this funding entails. I trust that you have an idea of the tension in my own head and heart at this point.

It is against this background that this article is aimed at exploring the work of SU as a mission-based youth ministry model in Africa in view of the present call to decolonise theology. My approach would be to briefly discuss this call for decolonisation; reflect on how this would impact ministries like SU and make recommendations in view of opportunities I see for youth ministry to flourish in Africa. This will be done through reflecting through both a practical theology and missiological lens. Focus is placed on early missionary endeavours (because of the manner in which SU was founded) and its impact on a decolonised African context today. Because of the vast nature of the decolonisation, interdisciplinary voices will be included. This approach then is true to the intra-disciplinary and interdisciplinary nature of practical theology as discipline (Osmer 2008). The aim is not to make final conclusions on what it means to decolonise youth ministry in Africa as this concept has varying connotations depending on the context in which it is used.

\section{Problem statement}

Youth ministry cannot exist without taking seriously the faith formation of the youth being ministered to. By faith formation, I refer to the continual process of young people growing in their faith in order to reach spiritual maturity in Christ (Weber 2014). By faith formation, I also refer to identity and moral formation because I understand these three aspects of one's being as integrally related and connected to one's development (Weber 2015:5). Youth faith and identity formation impact how they live, the decisions and life choices they make and how they understand their faith amidst contesting faith traditions and world views. When these are not fully understood in how we do youth ministry, young people do not 'own their faith', resulting in them not maturing in their relationship with Christ. Youth ministry models that do not take this three-pronged integration seriously hinder the sustainable development of youth ministry and also the possibility of maturity in Christ for the youth themselves in Africa. 'Amidst the importance of a universal Christian faith grounded in the redemptive work of Christ, lies the uniqueness of individuals' contextually grounded and influenced faith' (Weber 2015:5).

\section{Early church history attests that as:}

Christianity spread beyond the Jewish community into Gentile community, the church was faced with a crisis. How should it respond to the challenges brought on by the influx of other into its community that had a Jewish foundation and development? An important decision was taken by the first Christian Council that met in Jerusalem (Acts 15), which had major significance for inculturation of the Christian faith if the non-Jewish Cultures. The apostles decision freed gentile Christians to express their faith without embracing the Jewish cultural practice of circumcision (Acts 15:18). The mission model of the New Testament church was accommodational. (Luzbetak 1996:86)

Discussions about decolonising or contextualising youth ministry models in Africa need to consider how foreign models have enhanced the faith formation of youth in this context. This then means that young leaders groomed from these models should be able to continue the work by using localised youth ministry models relevant to the context they are ministering into. The assumption at this point is that this is not the case. Many merely duplicate the use of foreign models like SU without critically engaging what these have contributed to the youth of this continent. One of the reasons foreign models have been welcomed without criticism has been because Africa and its youth are often negatively portrayed by the media to the outside world, while Western culture has mostly been portrayed in a favourable light and associated with freedom, justice, equality and emancipation (Weber 2015). Youth ministry models employed in Africa need to stem from the contextual situations and readings of the biblical text in which it finds itself. It cannot merely be adopted based on the fact that it stems from favourable international examples. The primary research question posed in this article asks: To what extent has the work of SU Africa been contextualised and decolonised for the sake of youth ministry on this continent?

\section{Brief history of Scripture Union in Africa}

Scripture Union has been operative in Africa since the late 1800s. It is reported that most missionaries came here to work 
as teachers or in government (Hews 2000:82). The full impact of its ministry will not be exhaustively traced because of the many personal testimonies that have most likely not been recorded (as with many African stories). The core of this section is based on two specific SU publications and the information sourced from two SU websites.

Scripture Union International was founded by an American; Payson Hammond in London in 1867 and was first known as the Children's Special Services Mission (Prest 1988:11). The name developed from the Children's Bible Union to the Children's SU to Young people's Scripture to SU (Prest 1988:16-17). This ministry was started based on the Hammond's personal conviction that children were able to understand enough to place their faith in Christ (ibid). Scripture memory cards, beach Bible clubs, camps and missions and school ministry seem to have been the core ministry of this organisation. It believed itself to be an aid to the Church through helping with evangelism and discipleship through developing life skills that would enhance the Christian character and witness of a child and promote Bible reading among people of all ages (ibid).

Scripture Union was operative in South Africa by 1879 through helping children to read the Bible (Prest 1988:19). Its superintendent of Secretaries was an Englishmen; Rev. Dr Hole (ibid). English was the main language used but this changed by 1893 when the material was made available in Dutch and a few African languages (Zulu, isiXhosa and Sesothu). Australian, Major Henry Guise led the charge with ministry into high schools in Ficksburg, South Africa, in 1902. $\mathrm{He}$ was assisted by Jessamy Sprigg, prime minister's daughter, to open access to schools in South Africa in 1904 (Prest 1988:21-22). Despite SU being known today for its ministry in schools, its history portrays a struggle to establish itself in schools because the format of SU needed adaptation for our schooling system. 'One influential reason given was that South Africa should have its own scheme, rather than anything that anyone else was following' (Prest 1988:24). Another reason was that the Students Christian Association (SCA), which was already active in schools, was mainly Afrikaner led and was reputable for its 'Afrikaner isolationism' (ibid). The two organisations wrested among each other for years. Scottish missionary, Mr AC Playfair, alongside the Berea Mission and South African General Mission, initiated the famous Star Seaside Holiday clubs for underprivileged children in Natal in 1885 (ibid:26-27). This followed the trend of SU of working alongside mission organisations in reaching children and eventually families for Christ through Scripture memory. To date SU offers various forms of training and life skills programmes in 10 regions in South Africa (Scripture Union South Africa 2017).

Scripture Union's ministry spread from South Africa to Ghana (1953), Nigeria (1958), Swaziland (1969), Botswana to Lesotho (1975) and later Namibia, Sierra Leone, Uganda, Zambia, Zimbabwe and others. It is reported that ministry here excelled because of its connection to school Bible clubs (Hews 2000:82). Scripture Union is presently active in 45
African states (Scripture Union International 2017). In 1953, the first SU camp in Africa was held in Winneba, Ghana (Hews 2000:53). The main focus was on boys (as these were the ones who came) of all races, tribes and ages (ibid). In order to populate their schools, the missionaries had to compete with others who had rights over children as their own sons and daughters, foster children, pawns or slaves. Riis reported in 1847, 'Girls we cannot get yet, since they are used as slaves, and people do not wish to miss their work' (Hewitt 2012). The first English missionary sent to work in Ghana came in 1955. Nigel Sylvester placed his ministerial emphasis on biblical doctrine and racial equality. School ministry also flourished in Nigeria under the leadership of John Dean who worked alongside the Sudan United Mission (Hews 2000:54). Besides camps and school ministry, leadership training among local preachers became integral to SU's work in Africa. By the 1970s, SU and SCA were considering a merger because of the strong call for ministry among a politically aware youth in South Africa at the time. In 1977, a year after the Soweto uprising of youth in South Africa, a call to include mixed race young people in South Africa was made. Bill Williams expressed frustration at the many mixed race young people who had felt that they had no identity amidst the political issues prevailing (Prest 1988:210). It is reported that one of the biggest international SU conferences was held in Zimbabwe in 1985 (Hews 2000:95). This conference created space for various cultural dress, language, ways of worship and unification around SU's statement of belief (Hews 2000:96). Despite racial changes noted earlier, it is reported that this conference served as the official 'game changer' for many contextual changes.

\section{Lessons learnt from Scripture Union's ministry The call to contextualise}

Scripture Union became known as a para-church organisation passionate about reaching children with the gospel through Bible Memory and various activities. Ministry among underprivileged and illiterate children was also taken seriously (Hews 2000:12; Prest 1988:28-29). Language translation was also taken seriously. A Quakers conference addressing SU imperialism declared that:

... Scripture Union must become a truly international family of equal and autonomous national movements (in which) each national movement is free to fulfil SU's basic aims in a way that is appropriate to its own culture. (Hews 2000:59)

This conference also proclaimed that SU became a movement that:

had no social, racial or intellectual limits (believing) in the unity of all believers in Christ without distinction as to race, language, colour or social position, and their equal worth in the sight of God. (Hews 2000:60)

One of the challenges this organisation faced was its hesitance in working alongside locals. Most of its ministry was coupled with foreign mission organisations (SAGM, YWCA, et al.) 
and was led by international leaders, not local churches or local people. 'A glaring deficiency continued to stick out like a sore thumb: there was no Black staff worker in the movement' (Prest 1988:177). With this came the challenge of doing cross-cultural ministry. The:

... Afrikaans speaking people were of an essentially different religious culture and could not be handled in the same evangelistic situation. Thus (Frank) Millard deliberately concentrated on the English-speaking population, being convinced that the most serious spiritual need lay there. (p. 34)

Millard believed that the SCA would better minister to the Afrikaner. Sckalk Liebenberg was the first SU worker appointed to work among Afrikaans children. It took 36 years for his successor, Englishman Jim Walkey, to be appointed (Hews 2000:25). In the meantime, a gap in leadership to the Afrikaans children remained.

It was interesting to read that SU ministry among the Basuto people comprised $4 \mathrm{o}^{\prime}$ clock picnics with tea. Ministry in this context was noted as complex because: '... special skills were required for involvement in the Black scene' (Prest 1988:173). 'London was not always helpful ... As things are done in Great Britain, have been done, and ever shall be done, as they must be elsewhere, if the name is to be used' (Hews 2000:27). It was only in 1969 in Swaziland that SU's work in Africa was considered multiracial (Prest 1988:175):

In 1977 a decision was taken to appoint a staff member to develop the Black primary schools work. A couple of years elapsed before John Nthane took up such a position. His impact was immediate ... (p. 189)

Frank Shayi was later (1978) added as Schools Organising Secretary in Johannesburg. Philip Nkabinde and Odo Ratshivhombela followed in Soweto. By this time, concerted efforts were being made to 'localise SU presence'. This 'opened the door to shared leadership across many Southern African boundaries and introduced a concept of non-racial partnership in leadership' (Prest 1988:192-193). In discussing a possible merger between SU and SCA, Mr Masipa noted that too much emphasis has been placed on preaching and testimonies but not enough on 'solid teaching and a positive and living witness to Christ' (in Prest 1988:211). Discussion around recruiting and training black leaders continued but the detail of this is not recorded.

I would assume that the challenges SU faced at this point were that of taking the culture of the local people to whom it was ministering seriously. With respect to the culture of the African, every effort was made to destroy their identity as a people by ensuring that they did not openly develop any political, cultural and ethnic associations. Cohesive family units were also not tolerated (Karenga 1993:124). The slave owners treated education with utter contempt to the extent that their desire to keep Africans in subjugation contributed to the underdevelopment of the white society because most of them were semi-literate (Hewitt 2012:3). Karenga (1993:128) further states that free and slave Africans engaged in five basic forms of resistance to slavery: (1) cultural, (2) day to day, (3) abolitionism, (4) migrationism and (5) armed struggle. The machinery of control used by the system of slavery included law, security forces, the church and the introduction of a class system to divide and deny the African slaves from developing sufficient unity to build their own community.

Scripture reading and memory has been the core of SU's ministry around the world. By 1970, over 15000 South Africans were using the British Scripture notes and Daily Power booklets that were written in West Africa yet printed in South Africa. By 1984, Alive to God, another British SU publication, was launched for people who were not comfortable with a chapter-to-chapter reading of the Bible (Prest 1988:225). Bible use action groups were set up in local areas to equip people to use these materials. The challenge, however, was that these materials did not seem to flourish in South Africa. Black and white Afrikaans churches did not find these contextual enough and did not promote them (ibid:226). SU Bible reading material was published in and for Africa (Hews 2000:84). By 1970, most of the writers were African (ibid:85). According to Aloo O Mojola (in Mbaya \& Cezula 2016), Bible translation in the hands of the indigenous people grew the church in Africa tremendously:

The spread of the church in Africa was inextricably connected to the translation of the Bible into the local tongues. The new readers empowered to read the Bible for themselves in their own languages felt equipped to challenge and question missionary readings and interpretations of the sacred texts in their won languages. Once the Bible is in vernacular, it becomes the property of that people. It becomes a Yoruba Bible ... a Zulu Bible. (Aloo O Mojola in Mbaya \& Cezula 2016:nl)

One of the biggest challenges for developing countries has been funding for ministry, from which Africa has not been exempt. Missionary work required the protection and support of colonial powers. Particularly in the areas of education and other social services (Coe 2005:31). A call for localised leadership and ministry came with the threat of withdrawn finances from the international office (Prest 1988:30). One of the areas which was continued even long after localised leaders were appointed was within SU ministry in private schools. In the process of appointing a worker in the Eastern Cape in 1973; 'R1000 a year for three years and R15 a month for a black staff member was offered' (ibid:191), while when recruiting for private schools accommodation, a car and R200 a month was offered (ibid:197). An Englishman was appointed for this post. Hews (2000:84) reports that it was the regional council of African leaders who decided where and how money was spent. The challenge here was that not all these 'African' leaders were locals but included many internationals who worked in Africa. Economist Stan Du Plessis (2017:3) argues that part of the plight in Africa with regard to its own resources lies in the fact that the industrial revolution led to a new round of colonisation in the 19th century, especially in Africa and Asia. This was around the time SU leadership was being changed. Du Plessis (2017:6) adds that it was the countries where enslavement was most intense and where economic performance was compromised after independence, leaving Africa still dependent on the 
world. This then challenges the stereotype that local leaders cannot manage funding cannot hold true, instead there are many other economic factors at play. Many of the issues in Africa are related to how colonial empires geographically divided countries and shifted borders. Du Plessis (2017:7) adds that being landlocked harms the growth potential of a country in at least two ways: raises the cost of transport for international trade, dependence on neighbouring countries for access to the coast. There is then no possibility for feedback from the local population about the kind of infrastructure and development that would serve their needs and they would have liked to see, nor was there any local accountability for the investment that was carried out (ibid:8). From an economist's perspective, he notes that the decolonisation debate should, in the first instance, be about restoring rights, including political and economic rights (ibid:14).

Interaction with local leaders and also feedback from international conferences led to changes in how SU conducted ministry. According to Mbaya and Cezula (2016:4), Christianity is not foreign to the African soil stating that Africans have always had a positive view of the Gospel. African life, cultures and beliefs exist as an integrated system. Accordingly, Mbiti pointed out that an oral, non-written, non-propositional style of doing ministry is therefore just as valid. 'SU was forced to come to terms with its own restricted area of operation among White English-speaking South Africans and beat out a policy of non-racialism' (Hews 2000:206). This is amidst South African government policies on racial separation which continually challenged the movement. Youth organisations were seen as a threat in the political climate that prevailed in South Africa. Many were asked to close down:

For the first time SU found itself face-to-face with the realities of the total South African situation. A strong black voice reacted powerfully to any suggestion of separateness between Black and White in the organizational and insisted that Scriptural principles alone guide the decision-making, regardless of difficulties or implications. (p. 208)

In terms of gender, not much is mentioned about women being involved in the early leadership or ministry of SU. Mention of three ladies under the localised banner of Africa Evangelistic Band (AEB) working alongside SU in Struisbaai is the only mention I could trace. The AEB was founded in '... -1924 as the outcome of the Evangelistic work of the Misses Garrat and Miss Cameron in South Africa'. According to Hews' record, the first appointed female worker in South Africa was Kitty Hamilton appointed in 1934 (Hews 2000:24).

A call for contextualisation seems to limit transformational change that is sustained beyond models used, leadership and resources offered. For this reason, we now consider what a decolonised approach to youth ministry in SU would look like.

\section{The call to decolonise}

One of the challenges imposed by mission organisations to Africa has been that they have not taken the cultures of the local people seriously. Youth ministry that takes the social needs of its young people seriously include those cultural experiences within African communities that these youth encounter daily (Weber 2015:5). Most youth ministry books read like cultural handbooks for middle-class and developed contexts (Myers 1991:400). Myers (1991:402-403) elaborates on how many youth organisations (founded within these contexts) have been created to place children and youth under the constant control of adults in the name of citizenship, leadership or character. This problem has increased distorted notions of powerlessness among youth (Weber 2015:2). Youth ministry will have to integrate ways of addressing the social challenges these youth face alongside their faith formation process (Nel 2005:75-76). The gospel message needs to be relevant to the cultural context these youth find themselves in through youth ministry models employed (Bujo \& Muya 2008:191; Kiaziku 2009:19).

There are many definitions for the term 'decolonisation' depending on the context in which it is used. Achille Mbembe (2015) describes decolonisation of knowledge within university as the de-privatisation and rehabilitation of the public space that begins with redefining what is public. Within university spaces, this would include decolonisation of buildings, democratisation of access, a sense of common good and a sense of citizenship. It would thus include developing pedagogies of presence. For Mbembe (2015:35), decolonisation is not contextualisation, rather a replacement of what colonial missionaries put in place. Ngugi (2000) adds that it is not an event that happens once for all at a given time and place, but an ongoing process of seeing ourselves clearly. It is rejecting the assumption that the modern West is the centrality of Africa's consciousness and cultural heritage. It is about rejecting the notion that Africa is merely an extension of the West. Decolonising is not about closing the door to European traditions. It is about placing Africa at the centre of all we do.

Colonialism is a system that survived colonialism, and continues to dehumanise the oppressed. Some theorists have argued that dehumanisation is not limited to the oppressed, but extends from the oppressors, as they themselves are dehumanised (Freire 1970). Hayden Burgess (2000) discusses five steps of colonisation crucial to the process of decolonisation that would help us distinguish it from contextualisation. Step 1 is denial and withdrawal. Foreigners (missionaries) look upon the indigenous as a people without culture, no morals, nothing of any social values to merit kind comment. By doing this, they deny the very existence of a culture. There have been many debates around conversion and its relationship to one's culture in African Christianity (Waweru 2016). Referencing the work and legacy of John Mbiti, Waweru notes that according to Mbiti:

conversion does not mean abandonment of ones culture for another culture. Africans were so receptive to Christianity that it took a very short time for the missionaries to convert them to new ways of life. (p. 3)

Sadly, the indigenous people themselves gradually withdraw from their own cultural practices, resulting in a delay in 
criticising what has happened to indigenous societies. Coe (2005) adds that:

different missions had different understandings of local languages and the customs they encountered ... in their efforts to document cultural experiences people ended up abandoning their ways of life ... this led to them condemning African customs as immoral and fraudulent, and they required new converts to break with their communities and families. This separation was perpetuated through schools in which children became the charges in mission. (pp. 29-30)

Such quick conversion made Mbiti think again about the abandonment of the African culture which he dedicated his life to (Waweru 2016). Even though attempts are made to give Christianity an African character, its Western form is in many ways foreign to African peoples. This foreignness is a drawback because it means that Christianity is kept on the surface and is not free to deepen its influence in all areas of African life and problems (Mbaya \& Cezula 2016:2).

The second step is that of destruction or eradication in which all forms of indigenous society are physically destroyed or eradicated. Once African cultural practices were rendered distant and abstract, some African Christians began rehabilitating those practices that they deemed worthwhile and compatible with Christianity as they sought to create an African nation...this resulted in a certain class of modern person separated from traditional ways of living (Coe 2005:30). For many traditional churches and youth organisations like SU, a change of colonial names and iconography whose function, all along, has been to induce and normalise particular states of humiliation based on white supremacist presuppositions would need to be re-imagined (Mbembe 2011).

In step 3, any continuing practice of indigenous culture is belittled or insulted as symbols of evil that must be replaced by those of the coloniser. A few semblances of the native culture are kept as a form of surface accommodation or tokenism evidenced as step 4. It seems as though the important components of local or indigenous culture have been maintained amidst all the greater changes. Debates around contextualisation have argued that this is what missionaries did. Instead of totally changing strategy, they would appoint local leaders and give resources to enforce their strategy at the expense of localised models. This could be considered when looking at how schooling was used as a medium for evangelism by foreign youth ministry models.

Finally, the traditional culture is transformed or exploited into the culture of the dominating colonial society as the final step. As countries emerged from the shadows of colonialism, especially in Asia and Africa, the churches founded by Western missionaries began to search for ways to shed their foreignness and to take firmer root in the local soil into which they had been planted. This process was known as indigenisation. However, there was a limitation with this process because in their effort to find indigenous religious and philosophical language and ideas to express Christian faith, it assumed that the Gospel would remain unchanged (Hewitt 2012:7). Indigenous art is an example of how indigenous culture has now been replaced as a basis for economic exploitation. Burgess notes that each phase can be experienced at the same time or in various combinations because they do not have demarcations.

Burgess (2000) then introduces five equally important phases of decolonisation. Because in the first instance of colonisation, all indigenous culture and symbols have been exploited, phase 1 would now mean a process of rediscovery and recovery takes place. Burgess argues that this stage is necessary because many indigenous people are struggling with inferiority complexes because they have been undermined in the colonial society they have been living in. This inferiority complex has been influenced by the many stories that have been supressed by alternate stories deemed more valuable than those of the local people. This resulted in social and political activities taking on new momentum. For Fanon (1961), struggles for decolonisation are first and foremost about self-ownership. They are struggles to repossess, to take back, if necessary by force that which is ours unconditionally and, as such, belongs to us. As a theory of self-ownership, decolonisation is therefore relational, always a bundle of innate rights, capabilities and claims made against others, taken back from others and to be protected against others once again, by force if necessary. In his eyes, self-ownership is a precondition, a necessary step towards the creation of new forms of life that could genuinely be characterised as fully human. Youth need to be disciple towards owning their faith and the models we employ should assist them in reaching this (Johnstone 2009). Mbembe (2011) adds that decolonisation is not about design, tinkering with the margins. It is about reshaping, turning human beings once again into craftsmen and craftswomen who, in reshaping matters and forms, need not to look at the pre-existing models and need not use them as paradigms. According to Burgess (2000), the phase of discovery and rediscovery has not ended. Many people are still unaware of how much has been taken from them, not knowing much of the details. The phase of rediscovery of one's history and rediscovery of one's culture, language and identity is fundamental to the movement for decolonisation. Another reason Burgess states for the importance of this process of rediscovery is that indigenous people can themselves abuse their culture. This can be seen how African youth leaders in these international organisations have failed in adapting these models to their local contexts. Many spend much time attending overseas conferences to meetings to maintain the original ethos of these organisations. This is why caution must be taken in letting media select for the colonised people the leadership or the identification of their cultural root.

People should be able to lament their victimisation through the second phase of mourning which is an essential phase of healing. Anger is one of the ways people deal with this phase. It is also difficult to generalise how long people remain in the mourning phase as this depends on circumstances: 
The harder I tried to make sense of the idea of 'decolonization' that has become the rallying cry for those trying to undo the racist legacies of the past, the more I kept asking myself to what extent we might be fighting a complexly mutating entity with concepts inherited from an entirely different age and epoch. There is something profoundly wrong when, for instance, syllabi (including Christian literature) designed to meet the needs of colonialism and Apartheid continue well into the post-Apartheid era. A Eurocentric canon is a canon that attributes truth only to the Western way of knowledge production. It is a canon that tries to portray colonialism as a normal form of social relations. They rest on a division between mind and world, or between reason and nature as an ontological a priori. (Mbembe 2011:8)

Burgess (2000) cautions that sometimes when there does not seem to be any alternative to the present condition, the mourning phase seems to be the only thing to do, which then accelerates the earlier stage of rediscovery and recovery. People then immerse themselves total in the rediscovery of their history, making for an interesting interplay between these two phases. This abuse of the mourning phase can turn into an attempt to entrench the colonisation in order to continue the mourning, the anger, the hating and the division of people. This then results in long-term grumbling. The spread of the Gospel in efforts to evangelise Africa was also perceived to mean that European culture was being shared with uncivilised cultures (Hewitt 2012:13). At the top of the pyramid were the white Europeans, and at the bottom were the black Africans. In this cultural matrix, the so-called civilised European culture went to the top of the pyramid and the so-called primitive African or indigenous cultures went to the bottom. If the European heritage cannot be excluded in the process of indigenisation and inculturation, then even greater exploration will be required to determine what the meaning of African or to be black is within the missio-cultural context (Hewitt 2012:23).

The third phase of dreaming is considered as the most important because when people are allowed to dream, it enables new possibilities, debate, consultation and the creation of new social order. People get to consider what they desire from an owned culture, aspiration and structures of government. Burgess (2000) notes that:

There are many instances in which people who underwent 'decolonisation' merely underwent a change in position of the coloniser. See, for example, the constitutions of the newly emerged pacific island nations as well as African nations. Do they reflect more closely the social and legal culture of the immediate preceding colonizer or of the indigenous culture? Are those documents truly reflective of the hopes and aspirations of the people previously colonised? Or do they represent the colonial mentality which pervades the society at the time of foreign departure? Were they written or advised by colonial experts coming from a mind-set of Western political structures or were they drafted by the people themselves? True decolonisation is more than simply replacing indigenous or previously colonised people into positions held by colonisers. Decolonisation includes revaluation of the political, social, economic and judicial structures themselves and the development, if appropriate of new structures which can hold and house the values and aspirations themselves. (p. 150)
According to Mbiti's notion of a decolonised theology (in Waweru 2016):

African Christians should be standing on their own religious foundations rather than being carbon copies missionary Christianity. This is possible once the Africans accept the uniqueness of Christianity in terms of its flexibility to be edited by the African environment. Dialogue does not mean simply forsaking ones religious practices and all of a sudden embracing another religions practices. (p. 2)

This then means that ministry to youth today has to be present in the villages, schools and hospitals and ministering to the poor and the rich in cities and in town. The church has a Trinitarian task for Christian Theology today which is making sure African religious and cultural heritage are maintained (ibid). Considering youth (students) within university spaces, Mbembe (2011) adds that this stage would include these young people inventing a set of creative practices that ultimately make it impossible for official structures to ignore them. This can also be said of local ecclesial structures which do not consider the voices of youth in how youth ministry is conducted and the different possibilities of doing ministry that can be explored. An example of how dreaming could become a possibility is Ghana who were one of the first countries to gain independence from British rule and as such influenced other African colonies and countries:

Subjecting African tradition to colonial norms resulted in its rehabilitation by nationalist and anti-colonialist movements during the struggle for independence. African postcolonial states like Ghana attempt to appropriate and undercut the power of alternative political authorities. (Coe 2005:10)

Postcolonialism as part of the state rule in Ghana has included chiefs in its governance yet still undermines their authority (ibid:14). What more could be dreamt about for an energetic, resilient and hungry youth on this continent?

There is, however, the threat of rushing dreaming and not allowing this phase of dreaming to take its full course. Many are demanding immediate action, with a belief that reflection and introspection are not worth the time and effort in the development of a new social order. Those expressing impatience and even ridicule over dreaming often call for very short sighted goals measured generally by materialistic gains. An example of this would be that some have called for decolonisation as Africanisation. Fanon (1961) was extremely critical of the project of Africanisation because he did not trust the African postcolonial middle class at all. $\mathrm{He}$ thought the African postcolonial middle class was lazy, unscrupulous, parasitic and above all lacking spiritual depth precisely because it had 'totally assimilated colonialist thought in its most corrupt form'. More ominously, Fanon took a certain discourse of Africanisation to be akin to something he called 'retrogression' - retrogression when the nation is passed over for the race, and the tribe is preferred to the state. Like the work of many missionary organisations after AD 540s, Christianity became popular first at the royal courts, and spread only slowly, if at all, out into the 
surrounding countryside. In fact, it seems likely that Christianity remained a largely urban religion of the nobility throughout all the centuries of Christian Nubia. Even now, little is known of the early Nubian churches. This is, of course, partly because they ultimately perished; but few documents remain from the period (Hill 2006:107). This trend even followed SU as was read in the background earlier.

After people have been given the opportunity to weight the voices, release themselves from shackles of colonial patriotism and dream of a new social order, they are able to commit (phase 4). This commitment to a single direction is evident in a clear statement of a desired direction (Burgess 2000). This can only fully take place when people have not been forced to a premature resolution of historical injustices, thus limiting the losses of those whose interests are threatened in decolonisation processes. Only once consensus and commitment is reached can people move on to a decolonised society. This is not a reactive but proactive step and must include consideration beyond what has been historically undertaken to achieve independence. Burgess (2000) argues that social processes only change after the people themselves have sufficiently changed. So what does all this mean for youth ministry in Africa today?

\section{Opportunities for youth ministry in Africa}

This article has touched on many complexities connected to how a white British founded organisation doing ministry within an African context has taken place; but also how it impacted youth and their leadership. The phenomenon of contradiction is given greater clarity by Max Weber (1968:137) in his work on the social function of religion. He argues that in a relationship between religion and class, religion does not always function in ideological support of the dominant social order. Instead, it functions at different social layers and trends, often embodying both conservative and critical identities. In such situations, the same religion can serve to legitimise both the ruling class and the resistance of lower classes (Hewitt 2012:2):

If Black leaders are going to continue looking over their shoulders to blame White inability or ineptitude for the current predicament, they must understand that the predicament will be ongoing. What is needed is one Black leader- with leadership competence and spiritual standing- who prepared to look at the massive target-area of the future and say, 'Regardless of everything I am going to be proud of being Black and I am going to make SU relevant to this majority sector with God's help. (Prest 1988:233)

Theologians such as Idris Hamid and Ashley Smith (in Hewitt 2012:20) argue that the contemporary church cannot respond meaningfully to challenges with a colonised theology and colonial church structures. What is needed, they argue, is the emergence of a new church that will be fundamentally different from its predecessor. Young people on this continent face many complex challenges that require a multifaceted approach to youth ministry. Churches, faith-based organisations and theologians need to approach and prepare its youth by engaging in multidisciplinary ways. We need to expand our borders.

The last 20 years has seen a shift in SU leadership and contextual focus in ministry. One of the core challenges has been decreased funding because of this change which has resulted in a financial crisis experienced. Early church history testifies to an African heritage which was self-sustaining and religious prior to colonial input. Ethiopia had already been the first African nation to mint its own coins, now those coins showed the cross. They built many monasteries, including the famous Debre Damo, built on the site of an old pagan shrine. The church was defined in part by its liturgy, and it had a complex and rich liturgical from an early date. St Yared, who lived in the 6th century, is credited with the composition and compilation of an enormous number of hymns and chants for use at set times of the year and in praise of particular saints - as well as the invention of Ethiopian system of musical notation. This developed quire independently from the European system and was considerably more complex. This was used to write down songs much like Gregorian chant in Europe. Sudan also had a thriving Christian civilisation during antiquity and the Middle Ages. By late antiquity, this vast region, generally known as Nubia, had seen successive powers rise and fall (Hill 2006:107). Once African churches take the faith formation of its youth (in varying contexts) seriously, more priority on funding the efforts to reach them will be found necessary. I am of the opinion that many Christian leaders have influence in our government and societal contexts but have not been empowered to minister in their local churches. They have the business skills to assist the church and its youth but have not been given the opportunities because of a perpetuation of closed leadership. The more our ecclesial spaces become open spaces for dialogue and empowerment around what church should and can be, the more our ways of doing and being church would enhance a sense of owned faith.

A political youth movement called Young Pioneers was active in Ghana before SU arrived but was overthrown in 1966 (Hews 2000:82). Christian youth today need to be able to live out and experience their identity in Christ alongside morally engaging in society and growing in their faith. Hewitt (2012:53) notes that the Jamaican people who felt they had little choice but to change their religious affiliation and embrace the new Christian religion of the colonisers automatically brought on themselves a dialectical tension between the beliefs, values and behaviour of their culture and that of a missionary Christianity. This can be said as true for many youth in Africa today. The models and contexts in which youth ministry is done cannot merely mimic the formats or programmes handed down from European contexts. We need to take the rapidly changing pace and challenges facing youth on this continent seriously, especially from ecclesial contexts. There is a need for engagement with youth around issues related to their country's histories; their familial or tribal positions within those histories and also social justice around issues that impact their faith daily. The 
late 1900s seem to reflect a period in which SU leaders (local and international) placed an emphasis on issues related to social justice on our continent. An SU relief scheme in which money and food were provided was employed in Nigeria during its unrest in 1967 (ibid:83). An SU camp held in Zimbabwe (Rhodesia) reports of a white missionary sharing his blankets with black youth attending the camp without (ibid:84). SU leaders in Zaire addressed issues of corruption by forming an Honesty chain against accepting bribes in 1959 (ibid:85). The above understanding of the Gospel confirms that there is a direct relationship between the Christian faith and culture (Hewitt 2012:7). The Gospel can therefore become a destabilising force in any society because its goal is to make people to change their beliefs, values and behaviour. These areas of people's lives are firmly rooted within their cultural identities (ibid:8). It is necessary therefore for the Gospel to be communicated in culturally appropriate ways if it is perceived as meaningful by the recipients. Because the Gospel by its very nature must cross cultural frontiers if it has to communicate 'good news' to people, its authenticity will be determined, to a great extent, by the credibility of its messengers and the processes of its communication (ibid). Young people test this credibility by questioning structures and processes that seem inauthentic to them. They need authentic mentors and role models of what it means to be an African doing youth ministry on this continent.

Youth ministry in SU (as many mission organisations) used the medium of schooling to share the gospel with children and youth and still do today. Many local churches have also used and still do use this medium as a vehicle in which to do youth ministry. In the book, 'Dilemmas of Culture in African Schools: Youth, Nationalism, and the Transformation of knowledge', anthropologist Cati Coe reflects on what this relationship between schools and missionary endeavours have looked like in Ghana. Coe (2005) argues that schools become places where the relationship between state and its citizens is negotiated, with each side seeking to influence the other. How missionaries define culture incorporates:

practices of Christianity and schooling and Western ways' making it contextual and flexible ... it is also the ways people think about and enact their own personal ideas of culture ... Following the paths cut by missionary Christianity, all the discourses of culture currently operating in Ghana render culture a distant or abstract thing and a selection of the totality of everyday and ritual practices. (pp. 5-7)

Coe $(2005: 23)$ notes that for this reason, it is important to understand different role-players' perceptions of culture. Missionary understandings of culture are many times contradictory to that of the local cultural traditions. Missionaries linked language to the nation and provided opportunities for African Christians to document their own customs and history. Conversely, European ideas about labour and learning effectively separated schoolchildren and slaves from their families and communities, as they were brought under the patronage of the mission organisation... schooling was then the primary route by which people became Christian. Schools continued to be the way that children became Christian, which implied separation from their surrounding communities, signalled by wearing European clothes and not engaging in manual labour (Coe 2005:47). '...the church prohibited or at least discouraged practices seen as African' (ibid:48).

Waweru (2016) reports that John Mbiti (now famous for his decolonised theology) as a young boy herded sheep, goats and cattle while attending school. As the name of his birth place suggests, there was an open door for knowledge that shaped and prepared his mind for his interest in writing and the restoration of African religiosity. He then attended primary school at Kitui town, walking for about 8-10 km daily. While in high school, the spirit of writing caught up with him as he wrote his first novel Mutunga Na Ngewa Yake, which was later published. Mbiti lost the manuscript of his second novel which was in the hands of missionaries who were responsible for assessing and recommending publications in Kiikamba. He joined Makerere University College, Kampala, Uganda, an external college of the University of London, becoming one of the first students to graduate with a degree. It was during this time that he became very active in the Christian life of the university community when he received the vision to join the ordained ministry. He has become the measuring standard in terms of engaging the debate on the place of African culture within the Gospel (Waweru 2016).

Schools in Africa, as much a part of the colonial legacy are also associated with access to colonial power, entry into state employment and the rejection of conventional ways of living. African states have inserted culture into the curricular and extracurricular activities but this is problematic because of schoolings association with Christianity and cosmopolitanism (Coe 2005:10). Youth ministry within school contexts need to take this traumatic history into account. Getting quality education need not be conditioned to being Christian. Young people need to be equipped to live out their Christian faith within the challenges of our African schooling system yet still strive towards improving this system. It should not be an either-or system.

Another devastating element of the colonising culture was the consequence of colour. African self-hate was an integral part of the Western cultural design to display their indigenous value system with Eurocentric Christian norms. The participation of the missionary church was in demonised black identity that was not just an act of racial discrimination. Rather, the very identity of Jesus as the one who came to offer salvation to the people was presented not as a Jewish Jesus but as a white European (Hewitt 2012:62). The colour white became reinforced as a sign of victory and purity, while blackness was linked with not being up to standard (2012:63). In a paper entitled 'Discerning the role of faith communitiesin responding tourbanyouthmarginalisation', Nel (2014) says that youth interest has:

shifted in the South African context from what (he) would broadly call an emphasis on youth in relation to the struggle to overcome colonial racism, popularly known as 'the struggle against apartheid', to an emphasis on youth as the object of social inquiry and social welfare programmes, in the struggle against marginalisation. (pp. 1-2) 
He argues that 'it is also important to recognise the role of youth as the agents in initiating and driving such changes'. One of the ways in which a decolonised model of youth ministry can include the agency of young people would be to create safe spaces in which they could ask questions concerning their faith, morality and identity (Weber 2014). In Africa, the importance of storytelling between various generations cannot be overstated. 'Recalling one's life's experiences take place by means of song, dance, stories often with symbols taken from immediate natural contexts' (Cilliers 2017:8). This intergenerational sharing and dialogue encourages the conservation of values and traditions of the communities from which these youth come. As Cilliers (2017) puts it a 'rhythmic recalling and retelling of life'. Youth ministry cannot be restricted to racially allocated resources.

\section{Conclusion}

This article set out exploring the distinctions between contextualisation and decolonisation through using a British founded youth organisation (SU) in an effort to understand why this organisation and many other foreign youth ministries have continued ministry in Africa without adapting to the local context. It has discussed the distinction between the two, calling for an approach in which youth ministry models take the integration of young people's faith, identity and morality seriously. A lack of owned faith hinders the sustainable development of youth ministry and also the possibility of maturity in Christ for the youth themselves in Africa. Youth leaders in organisations like SU should be able to continue the work by using localised youth ministry models relevant to the context they are ministering into. Decolonisation is not contextualisation, which calls youth ministries in Africa to engage in an ongoing process of understanding the youth in our context and also the history of international organisations clearly. True decolonisation is more than changing leadership and providing funding. It is about re-reading the biblical text with the youth we minister to and exploring what this means for ministry with them on this continent.

\section{Acknowledgements Competing interests}

The author declares that she has no financial or personal relationships which may have inappropriately influenced her in writing this article.

\section{References}

Al-Zubaidi, L. \& Luckscheiter, J. (eds.), 2013, Perspectives. Political analysis and commentary from Africa: Movers and shakers? Böll Foundation Southern Africa, Cape Town

Burgess, H.F., 2000, 'Processes of decolonisation', in M. Battiste (ed.), Reclaiming indigenous voice and vision, pp. 150-160, UBC Press, Canada.
Bujo, B. \& Muya, J.I. (eds.), 2008, African theology in the 21st century: The contribution of the pioneers, vol. 2, Pauline Publications Africa, Nairobi, Kenya.

Cilliers, J., 2017, The Kairos of Kairos: Decolonising notions of temporality in Africa, Unpublished paper.

Coe, C., 2005, Dilemmas of culture in African schools: Youth, nationalism, and the transformation of knowledge, The University of Chicago Press, Chicago, IL.

Dean, K.C., Clark, C. \& Rahn, D. (eds.), 2001. Starting right: Thinking theologically about youth ministry, Zondervan Publishers, Nashville, TN.

DeVries, M., 2001, 'The myth of the perfect youth ministry model', in K.C. Dean, C. Clark \& D. Rahn (eds.), Starting right: Thinking theologically about youth ministry, Zondervan Publishers, US.

Du Plessis, S., 2017, 'Its rights not roads that will decolonise African economies. An economic perspective on decolonisation', Unpublished paper presented at Faculty of Theology Theological Day held at the Faculty of Theology, University of Stellenbosch, 24 August 2016.

Fanon, F., 1961, The wretched of the earth, Grove Press, New York.

Freire, P., 1970, Pedagogy of the oppressed, The Continuum International Publishing Group Inc., New York.

Hendriks, J., 2004, Studying congregations in Africa, Lux Verbi Publishers, Cape Town.

Hewitt, R.R., 2012, Church and culture: An Anglo - Caribbean experience of hybridity and contradiction, Cluster Publications, Nairobi, Kenya.

Hews, M., 2000, A tale of two visions: The story of scripture union worldwide, Creative Print and Design, Great Britain.

Hill, J., 2006, Zondervan handbook to the history of Christianity, Lion Publishing, England.

Johnstone, C., 2009, 'Faith crossroads and social networks: The transition from inherited faith to owned faith', Journal of Youth and Theology 8(1), 43-60.

Karenga, M., 1993, 'Introduction to black studies', in Racism: Essential readings, Sage Publishing Ltd., London.

Kiaziku, V.C., 2009, Culture and inculturation: A Bantu viewpoint, Pauline Publications Africa, Kenya.

Luzbetak, L.J., 1996, The church and cultures: New perspectives in missiological anthropology, Orbis Books, Maryknoll, NY.

Mbaya, H. \& Cezula, N., 2016, 'The contribution of John S Mbiti to the study of African religions, and African philosophy and biblical translations', Unpublished paper presented at conference on Decolonization of Theology at the Faculty of Theology, University of Stellenbosch, 23 August 2016.

Mbembe, A., 2011, On the postcolony, University of California Press Ltd., London.

Mbembe, A., 2015, Decolonizing knowledge and the question of the archive, Wits Institute for Social and Economic Research, viewed 15 February 2017, from http:// wiser.wits.ac.za/system/files/AchilleMbembe

Myers, W.R., 1991, 'Youth between culture and church', Theology Today 47(4), 400.

Nel, M., 2005, 'Why theology? It is only youth ministry', Journal of Youth and Theology 4(1), 9-22. https://doi.org/10.1163/24055093-90000124

Nel, R.W., 2014, 'Discerning the role of faith communities in responding to urban youth marginalisation', HTS Teologiese Studies/Theological Studies 70(3), 1-8. https://doi.org/10.4102/hts.v70i3.2743

Ngugi, W., 2000, Decolonising the mind: The politics of language in African literature, East African Educational Publishers Ltd., Nairobi.

Osmer, R.R., 2008, Practical theology: An introduction, Wm. B Eerdmans Publishing Company, Grand Rapids, MI.

Prest, E., 1988, Gems for his crown: The story of scripture union's century of service to South Africa, Scripture Union Publishing Agency, Cape Town.

Scripture Union International, viewed June 2017, from http://su-international.org/suaround-the-world/africa-region/

Scripture Union South Africa, viewed June 2017, from http://su.org.za/about-su/suhistory/

The Africa Evangelistic Band, viewed June 2017, from http://www.a-e-b.org/info/ who-is-the-aeb

Waweru, H.M., 2016, 'John Mbiti: The Canon of the African theology', Unpublished paper presented at conference on Decolonization of Theology at the Faculty of Theology, University of Stellenbosch, 23 August 2016.

Weber, M. (eds.), 1968. Economy and Society, Guenther Roth and Claus Wittich, Bedmin-ster Press, New York.

Weber, S., 2015, 'A (South) African voice on youth ministry research: Powerful or powerless?', HTS Teologiese Studies/Theological Studies 71(2), Art. \#2973, 1-6. https://doi.org/10.4102/hts.v71i2.2973

Weber, S.M., 2014, 'Faith formation of young people in an evangelical context: An empirical and theoretical investigation', Doctoral dissertation, University of Stellenbosch. 